UDC $911.2: 637.63(671.1)$

Theophilus Mukete N. Moto, Post Graduate Student (From Cameroon)

Odessa I. I. Mechnikov National University,

Department of Physical Geography and Environmental Sciences,

Shampansky lane, 2, Odessa, 65058, Ukraine

muketem2002@yahoo.com

\title{
MODERN THREATS TO FOREST LANDSCAPES: THE CASE OF OIL PALM CULTIVATION IN THE SOUTH WEST REGION OF CAMEROON
}

\begin{abstract}
Man's search for security, comfort and efficiency did not affect our ecology until very recently. Uncontrolled population growth and the concomitant additional requirements have led to deforestation and the destruction of the natural habitat for thousands of species. The use of bio-fuel to replace fossil fuel has equally opened new vistas to the cultivation of large agro-industrial oil palm plantations in heart of the humid tropical forest. One of the major challenging factors has been the systematic rape of the forest landscapes so that the environments are only a skeletal or shadow of themselves.

The purpose of this paper is to examine the ecological and socio-economic implications of such large agro-industrial oil palm plantations, more precisely the US-based agricultural company Herakles Farms, through its subsidiary SG Sustainable Oils Cameroon Ltd (SGSOC), to develop a 73, 000 hectare palm oil plantation under a 99-year land lease at the heart of five protected areas, situated in the fringe of world's second largest biodiversity hotspot in the South West Region of Cameroon.

The available data from secondary sources and field survey will guide the research study. The data will be analyzed and interpreted to reflect the events on ground. Cartographic, descriptive and comparative methods will equally be used.

Our findings reveal that the conversion of dense forest to oil palm plantation has led to the loss of biodiversity, disruption of the forest ecosystem, fragmentation of animal habitats, reduction in livelihood alternatives for the forest-adjacent communities and diverse conflicts. The author therefore, calls on the stakeholders and policy makers in Cameroon to enact laws that will prohibit the cultivation of oil palms in forested areas. Oil palms should be cultivated only on degraded landscapes to avoid these ecological and socio-economic impacts.
\end{abstract}

Key words: forest landscapes, deforestation, oil palm cultivation, landscape transformation, community conflicts, South West Region, Cameroon.

\section{INTRODUCTION}

The potential impacts of oil palm expansion on tropical forests and biodiversity in the world remain a tropical issue and a major conservation concern. The SG Sustainable Oils Cameroon, a subsidiary of American agri-business corporation Herakles Farms, in collaboration with the American non-profit All for Africa, 
exploiting a 73,000-hectare oil palm plantation in south west region of Cameroon is an example of negative human ingenuity on nature. Having examined this project in detail, we question many of the claims and practices of the project proponents, especially their insistence that the "plantations will follow the highest environmental and social standards, complying fully with Roundtable on Sustainable Palm Oil Principles \& Criteria". Like elsewhere in the world, Oil palm producers have always argued that forests are not being cleared to grow oil palm but analysis of land-cover data compiled by the United Nations Food and Agriculture Organization suggests that during the period $1990-2005,55 \%-59 \%$ of oil palm expansion in Malaysia, and at least $56 \%$ of that in Indonesia occurred at the expense of forests.

The same scenario is what is been experienced today with this dubious Herakles plantation which has violated all important RSPO rules and standards. On this regards therefore, such a project cannot be established at the heart of an ecologically vital area which is considered as one of the largest surviving tracts of lowland forest in the Gulf of Guinea without some negative foot prints on the biodiversity and the forest-adjacent communities which solely depend on forest resources for their survival. Moreover, the plantation is seen to have encompassed virtually the entire area linking five crucial protected areas in the region: Korup National Park, Bakossi National Park, Banyang Mbo Wildlife Sanctuary, Nta Ali Forest Reserve and Rumpi Hills Forest Reserve. Its development would fragment the regional landscape and completely isolate the surrounding protected areas.

It is on this view that some prominent authors have highlighted the impacts associated with oil palm cultivation in the tropical humid forest. The global extent of oil palm cultivation increased from 3.6 million ha in 1961 to 13.2 million ha in 2006 [4]. Today, oil palm is grown in 43 countries with a total cultivated area accounting for nearly one-tenth of the world's permanent cropland; [4]. As such, the potential impacts of oil palm expansion on tropical forests and biodiversity in the region are a major conservation concern [7] \& [14]. Despite the efforts been proposed by the European Commission, whose member states import palm oil as a biofuel feedstock, drafting a law to ban the import of fuel crops grown on certain kinds of land, including tropical forests [1], [3] oil palm cultivation most especially in forest landscapes are still multiplying.

Aware of the fact that forests hold a status of multi-purpose good and services for human needs ranging from medicine, fuel wood, forest and non-timber forest products (NTFPs) and arable land for food and cash crop production, there is dire need to use the forest sustainably since the replacement of forest to a mono-cultural crop will deprive the forest-adjacent communities from these forest resources which has been the source of their livelihood for decades. This is to make nonsense of the free gift from the bounty of nature, at the same time making it uncompromising for the future generations from making a viable living from these same forest landscapes [4]. But in spite of these the forest is disappearing through oil palm agriculture which is known to be accompanied with the greatest immediate threat to biodiversity. 
Perhaps some of the mitigation measures have been steps such as protecting riparian buffers, leaving patches of natural forest within plantations, and growing flowering plants in the understory of oil-palm plantations generate, at best, minor increases in the number of forest-dwelling species in plantations [6]. According to the author this measure has done nothing to improve on the landscape level, on the contrary it has resulted in isolated patches and narrow strips of forest within a vast matrix of oil palm. Some of these steps may be desirable for other reasons [8], [12], \& [13], such as improving water quality or protecting oil palms from insect pests [5], but they do little to conserve the imperilled fauna and flora like the case of Southeast Asia's tropical forests. The socio-economic loss of the forest-adjacent communities, like the case of the rural communities in the South West Region of Cameroon which has spark off major conflicts remain another issue of great concern.

The purpose of the paper is to critically examine the environmental and socioeconomic effect of oil palm cultivation by a subsidiary of American agri-business corporation Herakles Farms, in collaboration with the American non-profit All for Africa, exploiting a 73,000-hectare oil palm plantation in south west region of Cameroon.

The specific objectives of the study were:

- to examine the ecological and socio-economic implications of Herakles oil palm cultivation in the South West Region of Cameroon;

- to examine community conflicts and reactions of the forest-adjacent people to the Herakles oil palm project in the South West Region of Cameroon;

- to propose immediate and long term solutions to the problems associated with oil palm cultivation in Cameroon.

\section{DATA AND METHODS}

To better understand the impact of oil palm cultivation to forest landscapes in the South West Region of Cameroon, both quantitative and qualitative research techniques were used. The standard Geographical Science methodology was used for data collection, analysis and interpretations. Descriptive and comparative analysis was used to relate the impacts witnessed elsewhere in the tropics. Existing literature constituted the basis for further analysis of the problem under study.

These literatures were gotten from the Cameroon Environmental and Social Science Research Centre, Buea, the central library of the University of Buea, Cameroon and the Departmental Library of the Faculty of Social and Management Sciences of University of Buea, Cameroon. Primary data were collected through direct field observation. The photos used in the study were taken by Green peace and Joshua Linder, and played a great role in illustrating the activities of the Herakles on ground. The internet and worldwide Web facilities that had a direct link with the work were consulted. 


\section{RESULTS AND ITS DISCUSSION}

Learning the landscape of an area is critical to understanding the present landuse patterns. The South West Region of Cameroon has undergone transformation of large parts of its natural ecosystems on the pretext of development. To date, little is known about the patterns and processes of this transformation and their relation with socioeconomic and biophysical aspects. The recent changes in the structure and composition of the 73, 000 ha of forests by the Herakles oil palm plantation has been the most alarming and has attracted greater concern both internationally, nationally and locally.

Fig. 1 by black color shows the 73,000 hectares of oil palm plantation in Cameroon being developed by Herakles Farms of New York City. This farm lies geographical on $0502.511 \mathrm{~N}$ and 09 28.904E. The farm sits in the midst of numerous national parks and protected areas, shown in bright green, and conservationists are concerned that the oil palm development will impede wildlife migrations among the parks and lead to increased hunting of the region's animals and primates for bush meat by the forest-adjacent communities.

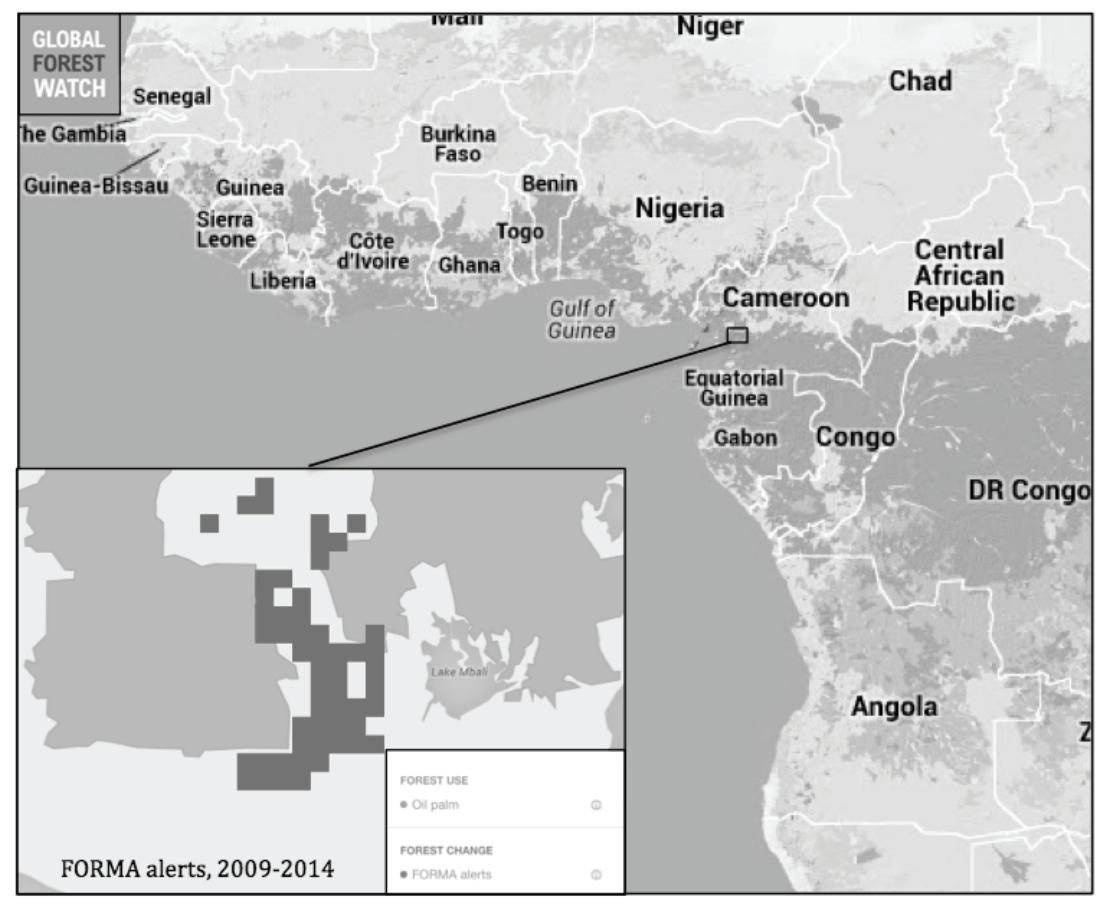

Fig. 1. Study area indicated in the Hexagon [2]

A US-based agricultural company Herakles Farms, through its subsidiary SG Sustainable Oils Cameroon Ltd (SGSOC), is presently developing a 73, 000 hectare 
palm oil plantation under a 99-year land lease, despite open community opposition, 2 court injunctions and an absence of government authorization. Local communities and environmental organizations have warned that the project will cause massive deforestation in a biodiversity hotspot (Fig. 2) and loss of livelihoods of indigenous communities.
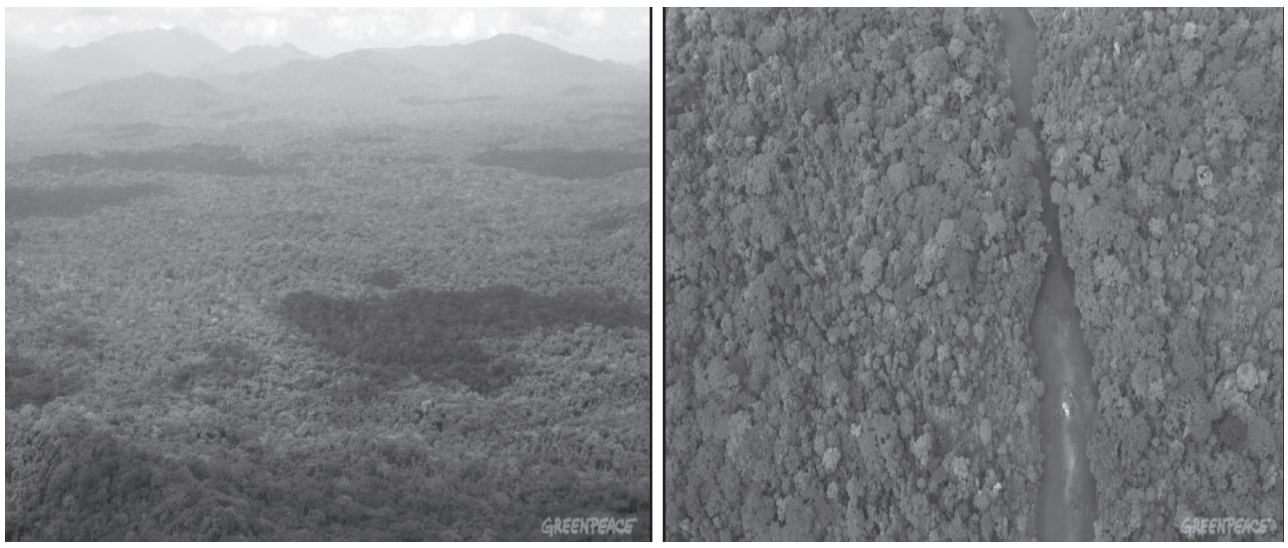

Fig. 2. Natural forest in Herakles site [13]

The severity of the issue pushed eleven of the world's top scientists issued an open letter urging the Cameroonian government to stop the project in April 2012. On the part of the indigenes the communities of Fabe, Massaka-Bima, Mbile, and Mundemba have equally sent complaint letters and petitions against the project to the government which in return the latter authorized the company to use a private security forces to evict people from the project area. A project which was highly embraced by the indigenous people when the Herakles Farms previously claimed its project would convert an area of little conservation value. But a study conducted by the University of Dschang, in collaboration with the University of Göttingen and supported by Greenpeace International, SAVE Wildlife and WWF Germany has found that claim to be a severe misrepresentation (Fig. 3).

This plantation cut across five protected areas in an eco-region considered to be the world's second largest biodiversity hotspot. With a total coverage of about 73,000 hectares, it is said to be one of the largest oil palm plantations in Africa. It is evidently clear that this type of forest bastardization could not occur without some severe ecological and socio-economic consequences on the forest landscape.

Ecological impacts. On the ecological front, the most important and sobering reality facing conservationists is that little can be done to make oil-palm plantations hospitable to biodiversity. The eradication of primary forest with a high degree of biodiversity to be replaced with a skeletal or artificial plant (Fig. 4) has caused severe loss in wildlife and agro-diversity on the one hand and loss of landscape/aesthetic degradation, deforestation and loss of vegetation cover on the other. 


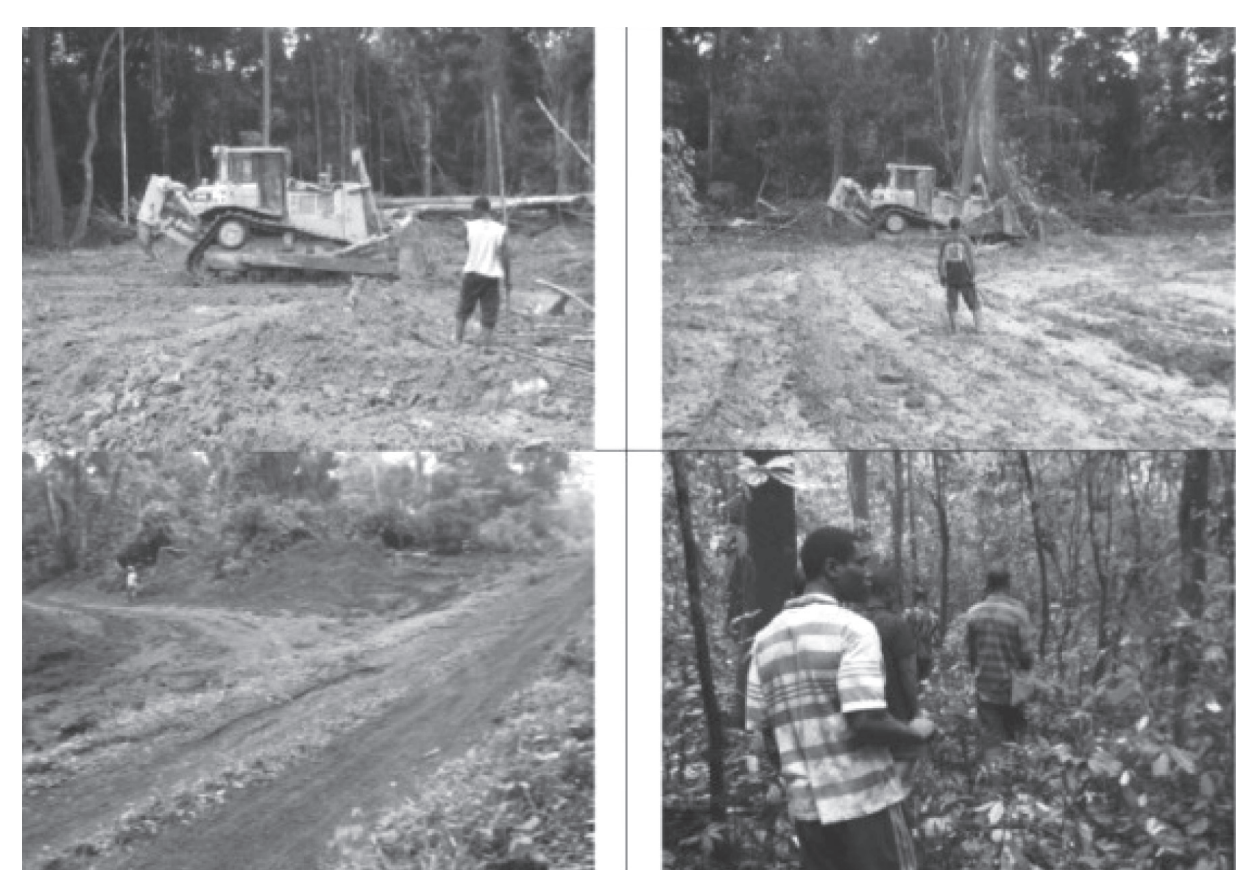

Fig. 3. After the destruction of the forest. Photo by Joshua Linder[13]

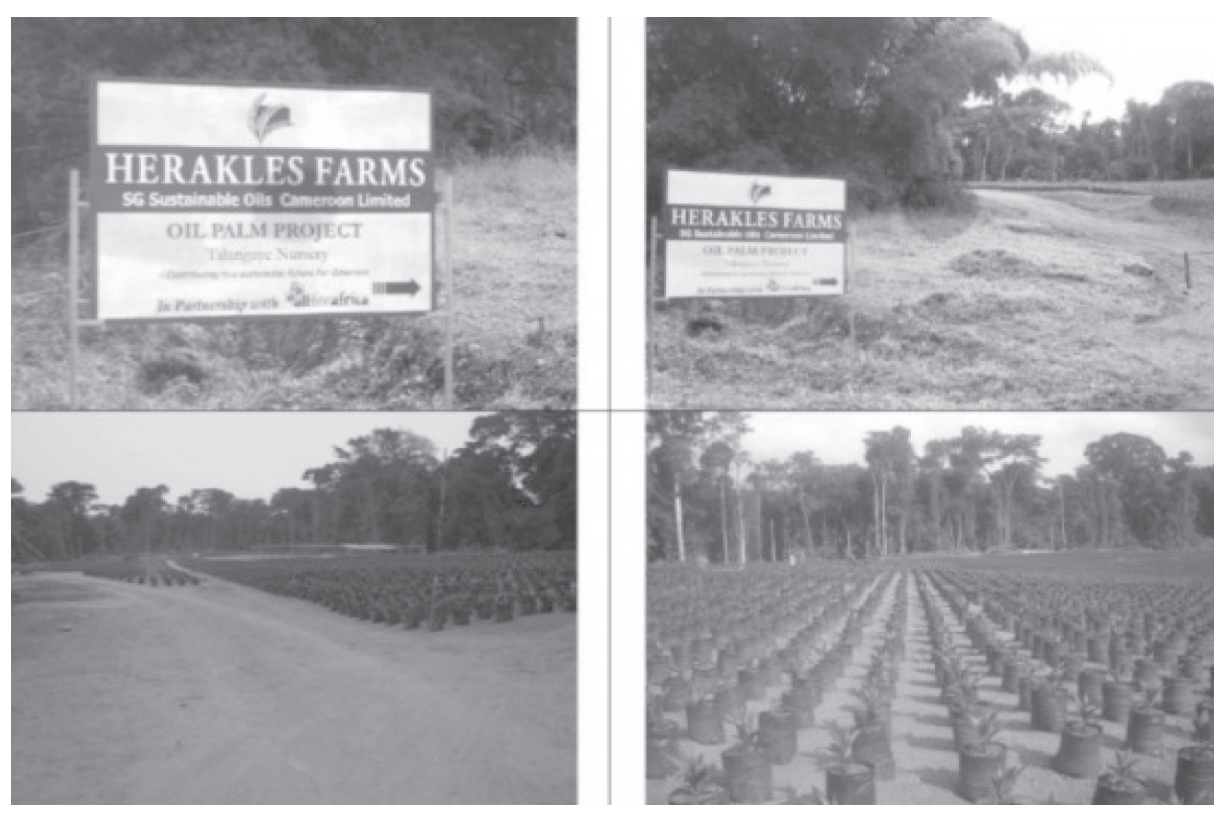

Fig. 4. Oil palm nursery near Korup National Park.

Photo by Joshua Linder [13] 
When an Environmental Study on Impact Assessment was carried out in 2012, the balance sheet showed great loss. It was found that the company had already destroyed 14.5 million trees of different species. The governments Rural Sector Development plan calls for palm oil production to triple to 45000 tonnes annually by 2020 . With such rate of forest degradation, it means in the nearest future tropical forests are bound to remain a skeleton.

According to the Research carried out by Greenpeace to show the impacts oil palm cultivation on the landscape and climate, their findings showed a negative balance sheet as they found this investment to pose dangers to the climate that largescale industrial expansion of the palm oil sector represents if it is allowed to continue unchecked.

Aware of the fact that this eco-region is considered a biodiversity hotspot which by induction is home to many endangered species including chimpanzees and forest elephants, it is obvious that these animals are bound to loss their habitats and become stray (Fig. 5). The eco-region equally provides a handful of services like hunting and fishing grounds, medicine for local communities to mention a few. All these environmental potentials are been threatened by the proposed palm oil plantation that would flatten an area eight times the size of Manhattan.
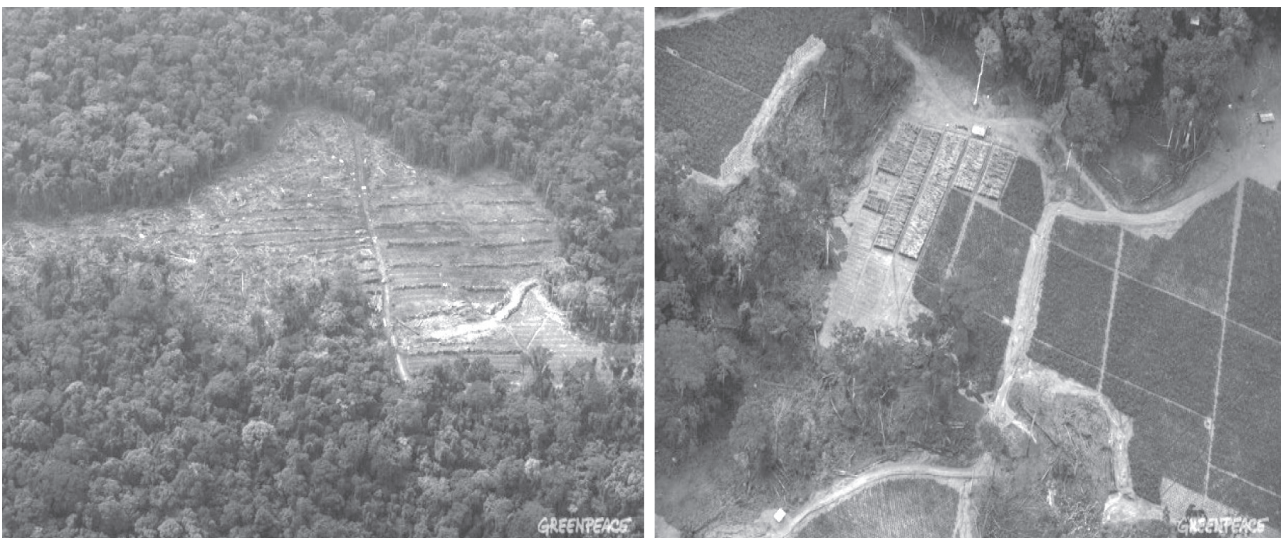

Fig. 5. Herakles Farm transformed forest to oil palm cultivation [13]

A revisit of the Management plans for Korup National Park [10] and Nta Ali Reserve [9] have indicated that this project has affected many animals, such as the threatened African elephant and chimpanzee and the endangered drill, actively use the proposed plantation area to forage and move among these protected areas.

Socio-economic impacts. The conversion of forests to oil-palm plantations has deprived the forest-adjacent communities of the ability to utilize forest resources which they solely depend on for their survival. Thus, there are serious humanrights issues associated with the expansion of oil-palm agriculture that merit further scrutiny. 
This new wave of land grabs for oil palm cultivation poses a major threat to the forest-adjacent communities. A handful of these communities have loosed access to vital lands and water resources, now and for future generations. They have equally been exposed to all the impacts that accompanied vast monoculture plantations within their communities. This includes pollution from pesticides, soil erosion, deforestation and labour migration just to mention a few. Experience also shows that the employment generated by the plantations often goes to outsiders, and that most of the jobs are seasonal, poorly paid, and dangerous.

Some of the visible socio-economic impact from this modern forest landscape threats is increase in Corruption/Co-optation of different actors, displacement, increase in violence and crime wave, lack of work security, labour absenteeism, firings, unemployment, loss of livelihood, loss of traditional knowledge/practices/ cultures, militarization and increased police presence, violations of human rights, land dispossession, loss of landscape/sense of place.

Specific impacts on women. Taking into consideration the fact that $70 \%$ of women in the forest-adjacent communities are responsible for the provision of household needs through the collection and harvesting of Non-Timber Forest Products, this project has frustrated many families from their sources of livelihood survival. Fuel wood which is the major source of energy in these areas has been reduced. All this only add to the frustration on how local communities can survive without having access to their immediate resources.

Community Conflicts. Depriving the communities from their only source of livelihood is an indication of war, since a hungry man is an angry man [11]. Understanding the details about the project has spark off fierce resistant from the forest-adjacent communities who claims they have not been compensated for their land. This project covers over 73,100 ha of land, with 750 million dollars expected in revenue. Mathematically the company is paying $\$ 0.50$ to $\$ 1$ per hectare per year and has a 99 year land lease. This simply means 1 hectare of land per year is sold for just an equivalence of 500 FCFA. This plantation will have major impacts on up to 45,000 Indigenous Peoples in 88 villages who are dependent on the forest and forest resources for their livelihoods. The plantation will also fragment and isolate the regions protected areas, including Korup National Park, Bakossi National Park, Banyang Mbo Wildlife Sanctuary, Nta Ali Forest Reserve, and Rumpi Hills Forest Reserve. These predicaments pushed the villages of Fabe and Toko into a protest action to stand against this land grabs in June 2012, but in response faced intimidation and arrest by police.

Till present tension between the corporation and the villagers continued to rise but the corporation and the government continued to claim that the local populations approved of the proposed concession and to spread disinformation in the domestic and international media. A majority of these people are openly opposed to the project. They claim they have had little or no consultation on what is to be done with their land, land that in a lot of cases has been worked by their families for generations. 
Bruce Wrobel, the Executive officer of the Herakles project says he is addressing a "dire humanitarian need". There is evidently a difference of opinion.

A major conflict recently occurred with the alarm of timber that the company is exploiting on the land without any indigenous compensation (Fig. 6).

"A large majority of local people are opposed to what Herakles is doing, and we wanted the world to see that reality" stresses Nasako a profound activist of the project.

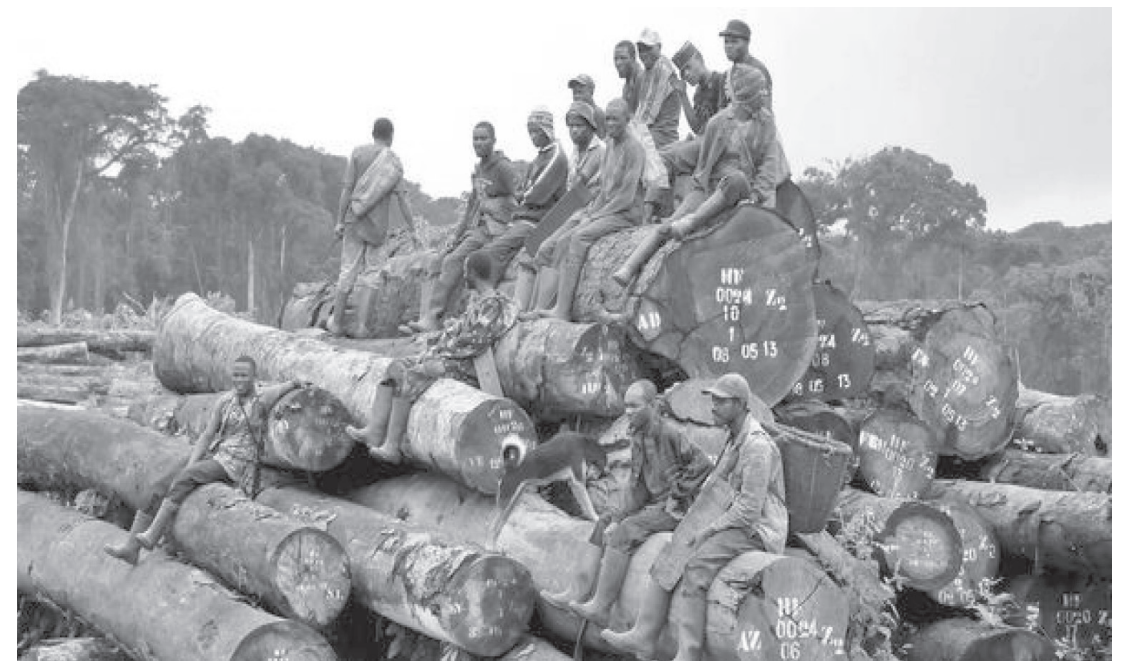

Fig. 6. Logged wood in the Herakles Project site [13]

In November 2012, at the request of the community, a popular NGO with the acronym "SEFE” Struggle to Economize Future Environment, drew up an action plan and produced hundreds of tee-shirts bearing the slogan: "No plantations on our land, SGSOC go home." The plan of the villagers was to wear these T-shirts at the inaugural ceremony for the new regional prefect, and in that way to express their opposition to the Herakles plantations. But it was rather unfortunate that before the ceremony took place, a squadron of police and soldiers burst into SEFE's office and arrested the profound activist Nasako and five villagers. "This action by the uniform men was to silence the action of the villagers but instead resulted into violence," states Nasako. "But we insisted that it was to be a peaceful demonstration and we urged people not to resist arrest, since that would just give them an excuse to make more arrests and file more complaints." Despite these bullying tactics, 400 people managed to put on the tee-shirts (Fig. 7). On their way to the ceremonial ground they were violently attacked and ones more brutalized by police and soldiers, who prevented them from entering or wearing the tee-shirts. 

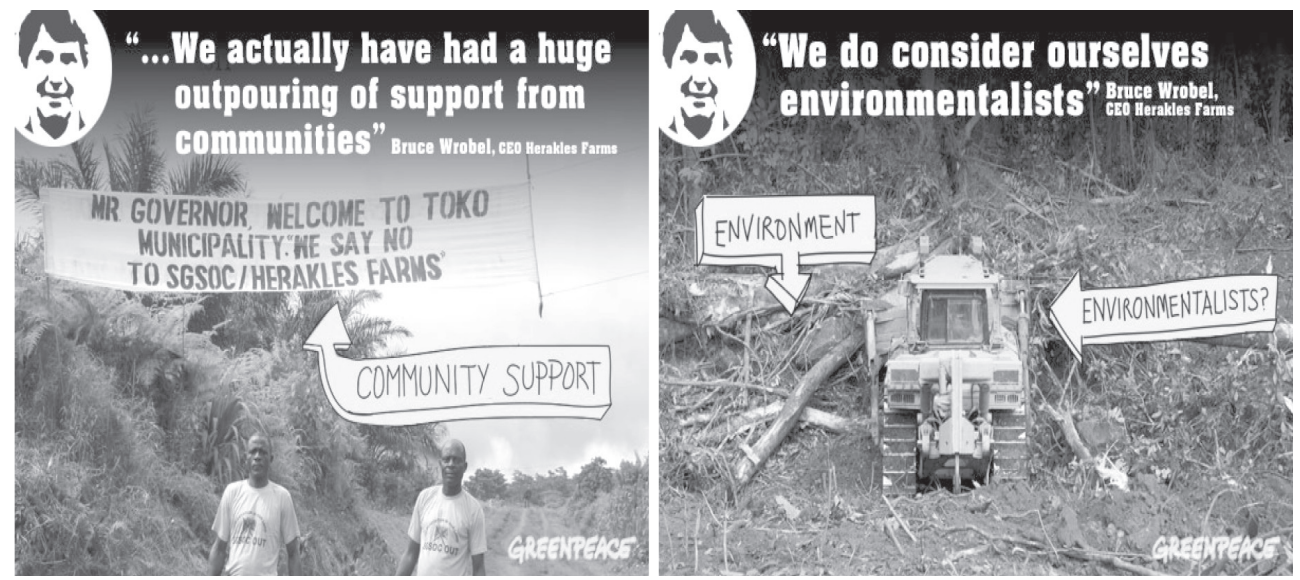

Fig. 7. Opposition from Local Communities in the project site

In January, 2017, the people of Nguti Sub division blocked all roads leading to the forest where timber is being exploited and taken to Nguti town for processing and identification. The protesters have also revealed the dubious nature of the timber.

\section{CONCLUSIONS}

The Herakles oil palm plantation located in the forested area of the Guinean forests of West Africa is an area known as a biodiversity hotspot. Since the project was first announced in 2009, the Herakles Farms in the South West region has been beset with controversy. The plantation has been operating illegally and linked to corrupt practices and many Cameroonian and international groups are calling for the cancellation of the project. The project has also been developed without the adequate consultation or free prior and informed consent of the forest-adjacent communities, many of whom oppose the project and risk the loss of their customary land and livelihoods. Cutting the ,heart' out of this contiguous rainforest region will not be without consequences. Populations of species in a large and intact ecosystem are viable whereas small and fragmented populations have a much increased extinction risk. For a detail analyzes on the biodiversity loss, a field survey is unavoidable.

Aware of the fact that oil palm cultivation poses huge threats on forest landscapes, most especially projects located at the heart of protected areas leaves much to be desired. This paper therefore advise stakeholders and the parties involved in large agro-industrial plantations like the Herakles project in the South West Region of Cameroon to grow oil palm on degraded landscapes. Within such landscapes in this modern time, the risks and dangers to humanity and environment are minimized. 


\section{ACKNOWLEDGEMENTS}

This article is writing is under the framework of the Department of Physical Geography and Environmental Sciences of Odessa National University named after I. I. Mechnikov, Ukraine. I wish to express my sincere gratitude to my supervisor Prof. Yuriy D. SHUISKY for his contribution to this article.

\section{REFERENCES}

1. Barlow, J. (2007), Quantifying the biodiversity value of tropical primary, secondary, and plantation forests: Natl. Acad. Sci. U. S. A, Vol. 104, pp. 18555-18560.

2. Courtesy of SAVE Wildlife Conservation Fund 2011, Yale University. Available online in http://e360.yale.edu/ content/images/0911-cameroon-palm-oil.html: Accessed in Dec. 31st, 2016.

3. Falcy, M. R., Estades, C. F. (2007), Effectiveness of corridors relative to enlargement of habitat patches in Conserv. Biol., Vol. 21, pp. 1341-1346.

4. Food and Agriculture Organization of the United Nations, 2006: Global Forest Resources Assessment 2005, pp.109-113.

5. Koh, L.P. (2007), Potential habitat and biodiversity losses from intensified biodiesel feedstock production in Conserv. Biol., Vol. 21, pp. 1373-1375.

6. Koh, L. P., Wilcove, D. S. (2007), Cashing in palm oil for conservation in Nature, Vol. 448, pp. $993-994$.

7. Koh, L. P., Wilcove, D. S. (2008), Is oil palm agriculture really destroying tropical biodiversity? Conserv. Lett., Vol. 1, pp. 60-64.

8. Lambert, F. R., Collar, N. J. (2002), The future for Sundaic lowland forest birds: long-term effects of commercial logging and fragmentation in Forktail, Vol. 18. pp. 127-146.

9. MINEF. 2001. Management plan for Nta-Ali Forest Reserve. Yaoundé, Cameroon, pp. 16.

10. MINEF 2003. A Management Plan for Korup National Park and Its Peripheral Zone in Government of Cameroon, Yaoundé, Cameroon, pp. 13-56.

11. Mukete, M. T. N. (2016), Community conflicts over forest resources in the Southern Bakundu Forest Reserve in International Journal of Resource and Environmental Management, Buea, Vol. 1, No 1, pp. 69-80.

12. Rajaratnam,, R. (2007), Diet and habitat selection of the leopard cat (Prionailurus bengalensis borneoensis) in an agricultural landscape in Sabah, Malaysian Borneo in Trop. Ecol, Vol. 23, pp. 209-217.

13. Reijnders, L., Huijbregts, M. A. J. (2008), Palm oil and the emission of carbon-based greenhouse gases in J. Clean. Prod, Vol. 16, pp. 477-482.

14. Scharlemann, J. P. W., Laurance, W. F. (2008), How green are biofuels? In Science, Vol. 319, pp. $43-44$.

Надійшла 03.03.2017

Теофілус Мукете Найомбе Мото, аспірант

Одеський національний університет імені I. І. Мечникова, кафедра фізичної географії та природокористування, пров. Шампанський, 2, Одеса, 65058, Україна

muketem2002@yahoo.com

\section{СУЧАСНА НЕБЕЗПЕКА ЛІСОВИХ ЛАНДШАФТІВ НА ПРИКЛАДІ ВИРОЩУВАННЯ ОЛІЙНОЇ ПАЛЬМИ В ПІВДЕННО-ЗАХІДНОМУ РЕГІОНІ КАМЕРУНУ}

Резюме

Людина в пошуках безпеки, комфорту та ефективності не впливала на нашу екологію до недавнього часу. Неконтрольоване зростання населення і супутні до цього додаткові вимоги призвели до вирубки лісів та знищення природного 
середовища існування для тисяч видів. Використання біопалива для заміни викопного палива в рівній мірі відкрило нові перспективи для вирощування великих агропромислових плантацій олійних пальм в серці вологого тропічного лісу. Однією з основних проблем є безперервна деградація лісових ландшафтів, в наслідок чого навколишнє середовище залишається без будь-якого рослинного покриву.

Метою даної роботи є оцінка екологічних та соціально-економічних наслідків дії на великі агропромислові плантації олійних пальм американської компанії HERAKLES Farms через свою дочірню компанію SG Sustainable Oils Cameroon Ltd (SGSOC) на 73000 га площі у продовж 99-річної оренди земельної ділянки в центрі п’яти охоронних природних територій, розташованих на кордоні 3 другою по величині у світі гарячих точок біорізноманіття в Південно-Західному регіоні Камеруну.

Стаття написана на основі наявних матеріалів із вторинних джерел і польових досліджень. Дані проаналізовані та відображають події на місцях з допомогою картографічного, описового та порівняльного методів дослідження.

Отримані нами дані показують, що перетворення густого лісу на пальмову олійну плантацію призвело до втрати біорізноманіття, руйнування лісової екосистеми, фрагментації середовища перебування тварин, скорочення альтернативних засобів до існування для лісової суміжної громади, і до різних конфліктів. Тому автор закликає зацікавлених сторін і осіб, що визначають політику в Камеруні, щоб вони прийняли закони, що забороняють вирощування олійних пальм в лісових районах. Щоб уникнути цих екологічних і соціальноекономічних наслідків, олійні пальми мають бути вирощені тільки на деградованих ландшафтах.

Ключові слова: лісові ландшафти, вирубка лісів, вирощування олійної пальми, перетворення ландшафтів, громадські конфлікти, Південно-Західний регіон, Камерун.

Теофилус Мукете Найомбе Мото, аспирант

Одесский национальный университет имени И. И. Мечникова, кафедра физической географии и природопользования, пер. Шампанский, 2, Одесса, 65058, Украина

muketem2002@yahoo.com

\section{СОВРЕМЕННЫЕ УГРОЗЫ ЛЕСНЫХ ЛАНДШАФТОВ НА ПРИМЕРЕ ВЫРАЩИВАНИЯ МАСЛИЧНОЙ ПАЛЬМЫ В ЮГО- ЗАПАДНОМ РЕГИОНЕ КАМЕРУНА}

\section{Резюме}

Человек в поисках безопасности, комфорта и эффективности не влиял на нашу экологию до недавнего времени. Неконтролируемый рост населения и сопутствующие к этому дополнительные требования привели к вырубке лесов и уничтожения естественной среды обитания для тысяч видов. Использование биотоплива для замены ископаемого топлива в равной степени открыло новые перспективы для выращивания крупных агропромышленных плантаций масличных пальм в сердце влажного тропического леса. Одной из основных 
проблем является непрерывная деградация лесных ландшафтов, вследствие чего окружающая среда остаётся без какого-либо растительного покрова.

Целью данной работы является оценка экологических и социально-экономических последствия действия на крупных агропромышленных плантациях масличных пальм американской компании HERAKLES Farms через свою дочернюю компанию SG Sustainable Oils Cameroon Ltd (SGSOC) на 73000 га площади в течении 99-летней аренды земельного участка в центре пяти охраняемых природных территорий, расположенных на границе с второй по величине в мире горячих точек биоразнообразия в Юго-Западном регионе Камеруна. Статья написана на основе имеющихся материалов из вторичных источников и полевых исследований. Данные проанализированы и отражают события на местах с помощью картографического, описательного и сравнительного методов исследования.

Полученные нами данные показывают, что превращение густого леса на пальмовую масличную плантацию привело к утрате биоразнообразия, разрушению лесной экосистемы, фрагментации среды обитания животных, сокращению альтернатив средств к существованию для лесной смежной общины, и к различным конфликтам. Поэтому автор призывает заинтересованных сторон и лиц, определяющих политику в Камеруне, чтобы они приняли законы, запрещающие выращивание масличных пальм в лесных районах. Во избежание этих экологических и социально-экономических последствий масличные пальмы, должны быть выращены только на деградированных ландшафтах.

Ключевые слова: лесные ландшафты, обезлесение, выращивание масличной пальмы, трансформация ландшафтов, социальные конфликты, Юго-Западный регион, Камерун. 